Boston University School of Law Scholarly Commons at Boston University School of Law

Faculty Scholarship

Summer 2015

\title{
What Will It Take to Address the Global Threat of Antibiotic Resistance?
}

Kevin Outterson

Boston Univeristy School of Law

Steven J. Hoffman

University of Ottawa - Common Law Section

Follow this and additional works at: https://scholarship.law.bu.edu/faculty_scholarship

Part of the Health Law and Policy Commons

\section{Recommended Citation}

Kevin Outterson \& Steven J. Hoffman, What Will It Take to Address the Global Threat of Antibiotic Resistance?, 43 Journal of Law, Medicine and Ethics 363 (2015).

Available at: https://scholarship.law.bu.edu/faculty_scholarship/8 


\section{BU School of Law}

\section{What Will IT TAKe to AdDRESS THE Global ThrEAT OF ANTIBIOTIC RESISTANCE?}

Boston University School of Law Public Law Paper No. 15-31

Journal of Law, Medicine \& Ethics - Summer 2015

\section{Steven J. Hoffman}

University of Ottawa; McMaster University; Harvard University

Kevin Outterson

Boston University School of Law

This paper can be downloaded without charge at:

http://www.bu.edu/law/faculty/scholarship/workingpapers/2015.html 


\title{
INTRODUCTION
}

\section{What Will It Take to Address the Global Threat of Antibiotic Resistance?}

\author{
Steven J. Hoffman and Kevin Outterson
}

$\mathrm{O}$ $f$ the many global health challenges facing the world today, only a small number require global collective action. Most health challenges can be fully addressed through action at local, regional or national levels.

What kind of actions must be taken to address the global threat of antibiotic resistance (ABR)? What legal, political and economic tools might be needed to achieve this level of action?

In March 2015 the Dag Hammarskjöld Foundation ${ }^{1}$ convened a workshop in Uppsala, Sweden to address these questions in partnership with the Global Strategy Lab, ${ }^{2}$ the Journal of Law, Medicine E Ethics $(J L M E),{ }^{3}$ the Norwegian Institute of Public Health, ${ }^{4}$ and ReAct - Action on Antibiotic Resistance. ${ }^{5}$ Eleven concise articles were commissioned to explore whether ABR depended on global collective action, and if so, what tools could help states and non-state actors to achieve it. This work built upon previous efforts of the Dag Hammarskjöld Foundation and its partners to address ABR, as well as instigate further research that is needed to inform relevant global policies, initiatives, and actions going forward.

Steven J. Hoffman, B.H.Sc., M.A., J.D., is an Associate Professor of Law and Director of the Global Strategy Lab at the University of Ottawa with courtesy appointments as an Assistant Professor of Clinical Epidemiology छ่ Biostatistics (Part-Time) at McMaster University and Adjunct Associate Professor of Global Health छ Population at Harvard University. He previously worked for the Ontario Ministry of Health छ' Long-Term Care, World Health Organization, and the Executive Office of the United Nations Secretary-General. Kevin Outterson, J.D., LL.M., is a Professor of Law and the N. Neal Pike Scholar in Health and Disability Law at Boston University School of Law, an Associate Fellow at Chatham House, and the Editor-in-Chief of the Journal of Law, Medicine \& Ethics.

\section{The Problem of Antibiotic Resistance}

This peer-reviewed $J L M E$ series begins with a detailed description of ABR. The medical evidence is clear that antibiotic resistance spreads across borders through many vectors. Tamar Barlam and Kalpana Gupta highlight the medical evidence that underpins the conclusion that resistance is a transnational health risk and thus a truly global problem. ${ }^{6}$ Even countries with extraordinary programs in antibiotic stewardship can face multi-drug resistant diseases when a traveler returns home from abroad.

While medical evidence is central to this effort, narrow disciplinary perspectives can hinder a full view of the field. To a physician, ABR is salient when a patient in the intensive care ward develops an untreatable and deadly bacterial infection. The problem is a lack of new drugs and the solution is to develop new treatments. To an infection control specialist, the problem is the nosocomial transmission of multi-drug resistant pathogens in hospitals. Solutions include better hospital infection control, including active surveillance. Public health officials might look even further back, at the chain of events that allowed multi-drug resistant bacteria to evolve due to improper antibiotic stewardship, including perhaps indiscriminate use of antibiotics among both humans and animals.

None of these disciplinary perspectives are wrong, but they give a limited view of a complex systems problem. For this reason, we sought from the beginning to include people from diverse academic and professional disciplines in this project, including physicians, public health practitioners, epidemiologists, economists, historians, lawyers, political scientists, and social activists - all of whom were committed to advancing global health, especially among the poorest populations on the planet. ABR is a complex problem, 


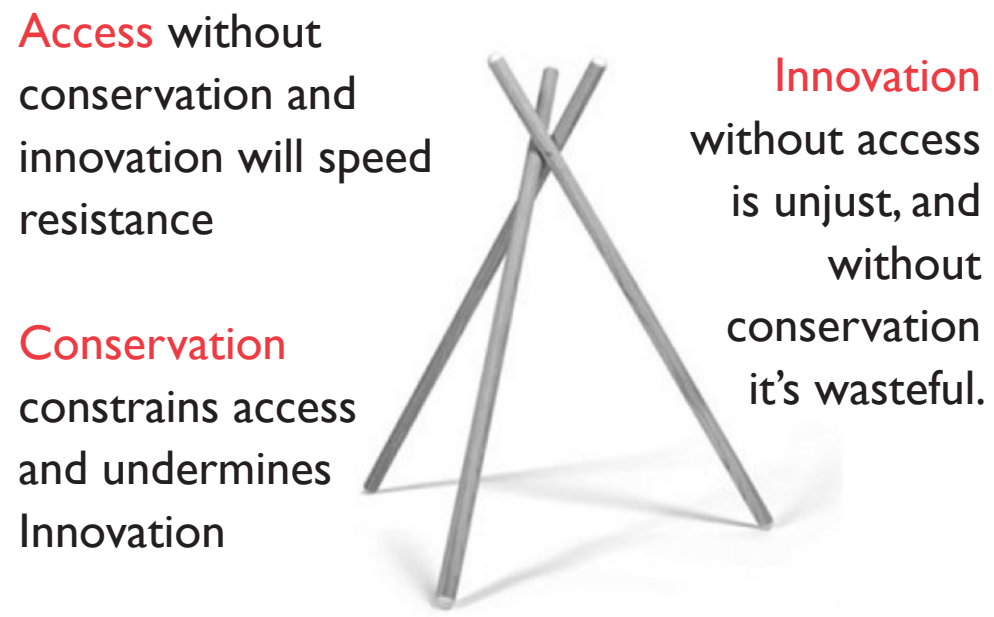

Access without conservation and innovation will speed resistance

\section{Conservation constrains access and undermines Innovation}

\section{Innovation}

is unjust, and

without

(

it's wasteful.

\author{
Our interdisciplinary \\ approach yielded a three- \\ pronged approach to \\ tackling ABR: (1) Access, \\ (2) Conservation, and (3) \\ Innovation.
}

one best addressed through interdisciplinary work including academics, clinicians and policymakers across varied contexts.

Our interdisciplinary approach yielded a threepronged approach to tackling ABR: (1) Access, (2) Conservation, and (3) Innovation (see Figure 1).7

Access, or lack thereof, is the cause of more people dying today from susceptible bacteria than from resistant bacterial pathogens ${ }^{8}$ despite warnings of a looming antibiotic apocalypse. ${ }^{9}$ Inadequate access to existing antibiotics is a global health crisis of the first order that currently receives insufficient attention. But antibiotic access cannot stand alone as a solution. Promoting global access to antibiotics will speed resistance unless it is coupled with strong conservation programs to ensure appropriate use. Access and conservation themselves may actually work at cross-purposes unless integrated into a single program. In addition, achieving universal access for low- and middle-income populations could undermine commercial incentives to invest in the research and development (R\&D) necessary to bring innovative new antibiotics to market. The article by Nils Daulaire and colleagues takes a bold stance on the crisis of antibiotic access, but they also recognize the imperative to integrate the solution with both conservation and innovation. While access could possibly be addressed on a country-by-country basis, an integrated solution requires coordinated action across borders.
Conservation cannot stop resistance, but it can certainly slow the rate of the emergence and spread of multi-drug resistant organisms. Conservation slows the rate of bacterial evolution, buying us time to develop alternatives. Conservation also includes activities that are welcome even in the absence of resistance because preventing an infection is always better than treating one. Public health measures like vaccines, clean food, safe drinking water, and infection control all support conservation by reducing the demand for antibiotics in the first instance. ${ }^{10}$ But conservation, despite many positive attributes, also faces obstacles. Conservation attempts to limit the inappropriate use of antibiotics, but the difficulty lies in defining "inappropriate," including use in resource-poor settings where access is the most pressing problem. Furthermore, conservation programs reduce the demand for antibiotics, which may encourage pharmaceutical and biotechnology companies to flee the field. Few companies want to step up R\&D investments in a declining market. Most importantly, conservation is a global collective action problem: while most conservation efforts will be implemented nationally, they work best when every country participates. For some countries, financial support will be necessary, as recently articulated in the World Health Organization's Global Action Plan on Antimicrobial Resistance. ${ }^{11}$

Innovation is the third leg of the tripod. We clearly need new antibiotic drugs to tackle emerging multidrug resistant diseases and the market is not responding adequately to the challenge. ${ }^{12}$ Traditional drug 
innovation models would promote either higher prices or larger volumes in order to drive innovation, but for antibiotics, the first would constrain access and the latter might undermine conservation. Crafting an effective new innovation model for antibiotics is necessarily a global endeavor, as described in this series by Manica Balasegaram, Charles Clift, and John-Arne Røttingen. ${ }^{13}$ They propose new global institutional arrangements to fund $\mathrm{R} \& \mathrm{D}$ and reward innovation for antibiotics, harmonized with the goals of access and conservation.

\section{Learning from Different Perspectives}

To broaden our understanding of the problem, this series also explores four additional disciplinary perspectives on ABR, rooted in history, economics, "One Health," and the environment. The recent work on the history of antibiotics is vibrant, woven together in the article by Scott Podolsky and colleagues. ${ }^{14}$ The antibiotic era is only seven decades old, but our collective memories need refreshing. Most salient to the present efforts are issues of who controls the use of antibiotics. Conservation and stewardship programs today are marching into prescriber autonomy battles that have been underway for decades in many settings. They also remind us that the current regulatory regime for prescription drugs was largely a response to problems with safety and efficacy of antibiotics. This is a timely reminder since the U.S. Food \& Drug Administration and European Medicines Agency have greatly relaxed those standards in recent years, specifically to boost antibiotic innovation.

Three key points arise from the economic analysis by Aidan Hollis and Peter Maybarduk. ${ }^{15}$ First, antibiotics are a global public good and the solution must address the "commons" problem. If we treated antibiotics as uniquely valuable and exhaustible, we would stop using them in low-value ways like animal growth promotion and human viral infections. Second, from an economics perspective, addressing the triad of access, conservation and innovation requires global coordination, as national-level solutions would be vulnerable to free riding, perverse financial incentives, and inadequate commitment mechanisms. Finally, they apply the work of Elinor Ostrom on the design and governance of coalitions to manage commons to emerging global governance options for antibiotics.

The One Health movement seeks to understand the many linkages between human and animal health, integrating approaches to improve planetary health. The task given to Anthony So and colleagues was expansive, and could easily have been the subject of its own series. But the primary message shines clearly through the mounds of data: human health and ani- mal health are deeply intertwined and therefore any solution to ABR must include, as a core component, animal health. ${ }^{16}$ It might be tempting to "simplify" the solution by cabining animal issues in a separate response, but that would be a profound mistake.

The final perspective article by Steinar Andresen and Steven J. Hoffman reminds us that ABR is not the only global collective action problem and that we have much to learn from how other sectors address "commons" problems like it. ${ }^{17}$ Their article benefits from the decades that Andresen has spent studying multilateral environmental agreements, first relating to oceans and more recently to climate change. They argue that while the international system is inherently weak, states can craft agreements to achieve global collective action if they are designed appropriately. In other words, institutional design matters. Learning from the environment, effective agreements include good procedures for reporting, enhancing compliance, and supporting implementation. Non-state actors must be engaged and mixed legal/political approaches should be considered.

\section{Moving Towards Global Collective Action}

The series ends with four articles that explore the mechanisms, instruments and forums available to states for achieving global collective action on ABR. Steven J. Hoffman and Trygve Ottersen highlight the need to put accountability at the core of any international agreement for it to achieve real-world impact. ${ }^{18}$ They start by defining "accountability" - a term used too often in so many different ways - as a relationship involving answerability and enforceability. Building on this definition, they sketch out a taxonomy of accountability mechanisms covering transparency, oversight, complaint and enforcement. This taxonomy then serves as a menu of options for global decisionmakers to embed accountability into the core of any kind of international agreement, either for ABR or other issues. Like guests at a restaurant, they do not recommend ordering every item from the menu. That might be unhealthy. But in the absence of empirical studies evaluating each mechanism's effectiveness, they advise global decision-makers to incorporate at least one mechanism from each category and rigorously evaluate their impact.

Questions around the exact kind of international instrument needed to address $\mathrm{ABR}$ are taken up in the next article by Steven J. Hoffman, John-Arne Røttingen and Julio Frenk, who make a strong argument in favor of pursuing an international legal approach. ${ }^{19}$ Whereas all three co-authors have previously taken stands against the adoption of new global health laws, ${ }^{20}$ they see something different in ABR. Specifi- 
cally, they think it is the only health challenge for which an international legal approach has thus far been proposed whereby (1) the problem has a significant transnational dimension, (2) the solution justifies the use of an instrument with coercive features, (3) the outcome of utilizing international law is likely beneficial, and (4) the implementation of needed actions have not been achieved through other instruments. These four features, which the trio put forward elsewhere as a cri- priate convening forum for pursing it will need to be made. Zain Rizvi and Steven J. Hoffman argue that just as much attention should be given to how and where global collective action on ABR is facilitated as the specific actions that are needed. ${ }^{23}$ This is because the success of any international agreement depends greatly on where it is negotiated and implemented. In their article, the two co-authors evaluate four different forums though which states could develop an interna-

Our goal for this series was to start providing evidence-informed guidance for how states and non-state actors could muster a comprehensive response to the global threat of $\mathrm{ABR}$ - addressing the access, conservation and innovation imperatives - while inspiring new lines of inquiry. We acknowledge this work is only a start because we know that much additional research and analysis is needed. Our real innovation here is having taken a scientific approach to global strategy whereby we drew upon a range of disciplines to systematically assess how instruments, institutions and initiatives could be designed to foster collective action on ABR and maximize impact. Our hope is that many more researchers, policymakers, activists, and social commentators will join the fray and continue this important work.

teria for considering new global health laws, ${ }^{21}$ make ABR uniquely well-suited for international legal intervention among the range of issues that vie for global decision-makers' attention.

Should the decision be made to pursue negotiation of an ABR international legal agreement, then the exact content of such an agreement will need to be crafted. Asha Behdinan and colleagues take up this challenge by assessing ten possible global ABR policies covering access, conservation and innovation and dividing them into three categories: those policies that depend on legalization to be effective (mostly conservation); those policies that would be strengthened if legalized (mostly access); and those that could be pursued separately but which might help mobilize support for implementation of the other ABR policies if included as part of a grand bargain (mostly innovation). ${ }^{22}$ The vitally important argument is that some conservation policies that are desperately needed to address ABR might be impossible to implement without the strength of an international legal agreement behind them. The collective action problems undermining action in some areas are just too great.

Following selection of the most appropriate international instrument, a decision about the most appro- tional legal agreement: self-organized venue; World Health Organization (WHO); World Trade Organization; and United Nations General Assembly (UNGA). While WHO and UNGA seem particularly promising, ultimately it is clear that an effective response is probably best coordinated through linked action pursued through several forums.

\section{Concluding Thoughts}

So, what kind of actions must be taken to address the global threat of ABR? Every article in this series points towards a common goal: the highest level of global collective action possible across countries, spanning sectors, and among all relevant stakeholders. What legal, political and economic tools might be needed to achieve this level of action? Each article reveals different lessons to be learned. While an international legal framework addressing ABR is recommended, such a framework is still only an implementation vehicle for other tools - whether those are global standards, funding agreements, industry engagement, monitored benchmarks, market incentives, or accountability mechanisms.

Our goal for this series was to start providing evidence-informed guidance for how states and nonstate actors could muster a comprehensive response 
to the global threat of $\mathrm{ABR}$ - addressing the access, conservation and innovation imperatives - while inspiring new lines of inquiry. We acknowledge this work is only a start because we know that much additional research and analysis is needed. Our real innovation here is having taken a scientific approach to global strategy whereby we drew upon a range of disciplines to systematically assess how instruments, institutions and initiatives could be designed to foster collective action on ABR and maximize impact. ${ }^{24}$ Our hope is that many more researchers, policymakers, activists, and social commentators will join the fray and continue this important work. If we wait too long, we might end up missing today's policy window that has been created by the Global Health Security Agenda launch in February 2014, the adoption of WHO's Global Action Plan on Antimicrobial Resistance in May 2015, the White House Forum on Antibiotic Stewardship and the G7's communiqué in June 2015, and the ongoing O'Neill Review on Antimicrobial Resistance in the United Kingdom, among many other contributing efforts and events.

We have many reasons to be hopeful. In the same month as this series is published, Professor Otto Cars, a grandfather of the ABR research field (and co-author of the second article in this series), was awarded Sweden's H.M. The King's Medal for his contributions to medical science. It demonstrates, in Professor Cars's own words, that ABR research "in the twilight zone inbetween science and politics is officially being recognized." ${ }^{25}$ We have also started to hear from the world's wealthiest countries that they are prepared to use public money to support antibiotics innovation. A major injection of sustainable financing for R\&D of antibiotics could transform the ABR challenge and provide the necessary political leverage to achieve progress on the access and conservation imperatives as well.

We conclude by thanking everyone who made this series possible, including all of our authors, peerreviewers, coordinators, and publishers. We are especially pleased with the timely process at $J L M E$ and our partners' commitment to open-access publication.

We hope you enjoy reading the series as much as we enjoyed editing it.

\section{References}

1. D. Hammarskjöld Foundation, "Who We Are," available at $<$ http://www.daghammarskjold.se/who-we-are> (last visited June 10, 2015).

2. Global Strategy Lab, "Mission," available at <http://www.globalstrategy.ninja/about> (last visited June 10, 2015).

3. American Society of Law, Medicine \& Ethics, Journal of Law, Medicine छ Ethics, "Back Issues and Articles," available at <http://www.aslme.org/Back_Issues_And_ Articles?journal=JLME $>$ (last visited June 10, 2015).
4. Norwegian Institute of Public Health, "Better Health for All," available at <http://www.fhi.no/eway/?pid=240> (last visited June 10, 2015).

5. ReAct - Action on Antibiotic Resistance, "Who We Are," available at <http://www.reactgroup.org/who-we-are.html> (last visited June 10, 2015).

6. T. F. Barlam and K. Gupta, "Antibiotic Resistance Spreads Internationally Across Borders," Journal of Law, Medicine ङ $^{\circ}$ Ethics 43, no. 2, Supp. (2015): available via aslme.org.

7. S. J. Hoffman, K. Outterson, J.-A. Røttingen, O. Cars, C. Clift, and Z. Rizvi et al., "An International Legal Framework to Address Antimicrobial Resistance," Bulletin of the World Health Organization 93, no. 2 (2015): 66.

8. N. Daulaire, A. Bang, G. Tomson, J. N. Kalyango, and O. Cars, "Universal Access to Effective Antibiotics is Essential for Tackling Antibiotic Resistance," Journal of Law, Medicine छ Ethics 43, no. 2, Supp. (2015): available via aslme.org.

9. Review on Antimicrobial Resistance, "Tackling Drug-Resistant Infections Globally, available at <http://amr-review.org/ home> (last visited June 11, 2015).

10. C. Clift, U. Gopinathan, C. Morel, K. Outterson, J.-A. Røttingen, and A. D. So, Towards a Nerw Global Business Model for Antibiotics: Report from the Chatham House Working Group on Nerw Antibiotic Business Models (Chatham House, 2015).

11. World Health Organization: Draft Global Action Plan on Antimicrobial Resistance, World Health Organization, available at <http://www.who.int/drugresistance/AMR_DRAFT_GAP_1_ Oct_2014_for_MS_consultation.pdf> (last visited June 11, 2015).

12. K. Outterson, J. H. Powers, G. W. Daniels, and M. B. McClellan, "Repairing the Broken Market for Antibiotic Innovation," Health Affairs 34, no. 2 (2015): 277-285.

13. M. Balasegaram, C. Clift, and J.-A. Røttingen, "The Global Innovation Model for Antibiotics Needs Reinvention," Journal of Law, Medicine E Ethics 43, no. 2, Supp. (2015): available via aslme.org.

14. S. H. Podolsky, R. Bud, C. Gradmann, B. Hobaek, C. Kirchhelle, T. Mitvedt, M. J. Santesmases, U. Thoms, D. Berild, and A. Kveim Lie, "History Teaches Us That Confronting Antibiotic Resistance Requires Stronger Global Collective Action," Journal of Law, Medicine $\Xi$ Ethics 43, no. 2, Supp. (2015): available via aslme.org.

15. A. Hollis and P. Maybarduk, "Antibiotic Resistance Is a Tragedy of the Commons That Necessitates Global Cooperation," Journal of Law, Medicine E Ethics 43, no. 2, Supp. (2015): available via aslme.org.

16. A. D. So, T. A. Shah, S. Roach, Y. L. Chee, and K. E. Nachman, "An Integrated Systems Approach is Needed to Ensure the Sustainability of Antibiotic Effectiveness for Both Humans and Animals," Journal of Law, Medicine E Ethics 43, no. 2, Supp. (2015): available via aslme.org.

17. S. Andresen and S. J. Hoffman, "Much Can Be Learned about Addressing Antibiotic Resistance from Multilateral Environmental Agreements," Journal of Law, Medicine E Ethics 43, no. 2, Supp. (2015): available via aslme.org.

18. S. J. Hoffman and T. Ottersen, "Addressing Antibiotic Resistance Requires Robust International Accountability Mechanisms," Journal of Lare, Medicine E Ethics 43, no. 2, Supp. (2015): available via aslme.org.

19. S. J. Hoffman, J.-A. Røttingen, and J. Frenk, "International Law Has a Role to Play in Addressing Antibiotic Resistance," Journal of Law, Medicine E Ethics 43, no. 2, Supp. (2015): available via aslme.org.

20. S. J. Hoffman and J.-A. Røttingen, "A Framework Convention on Obesity Control?” The Lancet 378, no. 9809 (2011): 2068; S. J. Hoffman and J.-A. Røttingen, "Be Sparing With International Laws," Nature 483, no. 7389 (2012): 275; S. J. Hoffman and J.-A. Røttingen, "Dark Sides of the Proposed Framework Convention on Global Health's Many Virtues: A Systematic Review and Critical Analysis," Health and Human Rights 15, no. 1 (2013): E117-E134; S. J. Hoffman and J.-A. Røttingen, "Assessing the Expected Impact of Global Health Treaties: Evi- 
dence from 90 Quantitative Evaluations," American Journal of Public Health 105, no. 1 (2015): 26-40; S. J. Hoffman, J.-A. Røttingen, and J. Frenk, "Assessing Proposals for New Global Health Treaties: An Analytic Framework," American Journal of Public Health (2015): e1-e8.

21. See Hoffman, Røttingen, and Frenk, supra note 20.

22. A. Behdinan, S. J. Hoffman, and M. Pearcey, "Some Global Policies for Antibiotic Resistance Depend on Legally Binding and Enforceable Commitments," Journal of Law, Medicine E' Ethics 43, no. 2, Supp. (2015): available via aslme.org.

23. Z. Rizvi and S. J. Hoffman, "Effective Global Action on Antibiotic Resistance Requires Careful Consideration of Convening Forums," Journal of Law, Medicine छ Ethics 43, no. 2, Supp. (2015): online only.
24. S. J. Hoffman, "A Science of Global Strategy," in J. Frenk and S. J. Hoffman, eds., "To Save Humanity": What Matters Most for a Healthy Future (New York: Oxford University Press, 2015): at $173-175$.

25. ReAct - Action on Antibiotic Resistance, "Royal Recognition and New Antibiotics Center Confirmed," available at <http:// www.reactgroup.org/news/496/18.html> (last visited June 10, 2015). 